\title{
In vitro biological effects of two anti-diabetic medicinal plants used in Benin as folk medicine
}

\author{
Fifa TD Bothon ${ }^{1,2,3}$, Eric Debiton ${ }^{1,2^{*}}$, Felicien Avlessi ${ }^{3}$, Christiane Forestier ${ }^{4,5}$, Jean-Claude Teulade ${ }^{1,2}$ \\ and Dominique KC Sohounhloue ${ }^{3}$
}

\begin{abstract}
Background: Extracts from Polygonum senegalensis (Polygonaceae) and Pseudocedrela kotschyi (Meliaceae) are two important traditionally used medicinal plants in rural Benin to treat many diseases and notably type 2 diabetes. The aim of the study was to investigate the a-glucosidase inhibition, antioxidant and antibacterial activities of those plants extract: Polygonum senegalensis leaves, and Pseudocedrela kotschyi root.

Methods: Hydro-alcoholic (50\%) extracts were analyzed for their phytochemical content and tested for their inhibition potency on a-glucosidase from Saccharomyces cerevisiae. Antioxidant activities were assessed using the DPPH, ORAC, FRAP and DCFH-DA (cell based) assay. Finally, the antibacterial activity was evaluated using MIC determination on four Gram-positive cocci (Bacillus subtilis, Clostridium difficile, Enterococcus faecalis, Staphylococcus aureus), three Gram-negative bacilli (Escherichia coli, Pseudomonas aeruginosa, Klebsiella pneumoniae), and the yeast Candida albicans.
\end{abstract}

Results: Each extract presented significant a-glucosidase inhibition and antioxidant activities. Polygonum senegalensis leaf extracts were the most active in each in vitro assay with an $I_{50}=1.5 \mu \mathrm{g} / \mathrm{ml}$ for a-glucosidase inhibition and an $\mathrm{IC}_{50}=6.8 \mu \mathrm{g} / \mathrm{ml}$ for DPPH scavenging, $-4.5 \mu \mathrm{mol}$ Fe II/g of dry matter $-9366 \mu \mathrm{mol}$ Trolox / g DW - for FRAP and ORAC values, respectively. IC $C_{50}=2.3 \mu \mathrm{g}$ GA / ml for DCFH-DA assay. Concerning its antibacterial activity, a growth inhibitory effect was observed only against three Gram negative bacilli: B. subtilis, E. faecalis, S. aureus and the yeast C. albicans at high concentration.

Conclusion: The results showed that the semi alcoholic extract of the two studied plants possess a-glucosidase inhibitory activity, antioxidant potency, and low antibacterial effect.

Keywords: Polygonum senegalensis, Pseudocedrela kotschyi, a-glucosidase, Antioxidant, Antibacterial

\section{Background}

Free radicals and other reactive oxygen species (ROS) generated in living organisms participate in many diseases including cancer, cardiovascular diseases, immunodeficiency, liver injury and infections [1]. Due to the huge costs of modern therapy for developing countries, the World Health Organization has estimated that $80 \%$ of the world's population use botanical medicine for their primary health care needs; so alternative strategies are urgently needed [2]. Many Plants were used in traditional medicine to treat a lot of pathologies. They play

\footnotetext{
* Correspondence: eric.debiton@inserm.fr

'Clermont University, Université d'Auvergne, IMTV, Clermont-Ferrand F-63000, France

2INSERM, UMR 990, IMTV, Clermont-Ferrand F-63005, France

Full list of author information is available at the end of the article
}

an important role in the life of rural people, particularly in remote parts of developing countries which do not possess important health facilities. Polygonum senegalensis (polygonaceae) and Pseudocedrela kotschyi (meliaceae) are two important traditional medicinal plants used in rural Benin to treat many diseases. They are used to treat diabetes mellitus, hypertension, gynaecological and wound infections. Some of these properties have been confirmed in other studies. For example Pseudocedrela kotschyi's antidiabetic [3] and antibacterial activities [4] were previously described. However, no mechanisms of action were described.

Recent interest in plant polyphenols has focused on their potential benefits to human health. The polyphenols are capable not only to reduce oxidative stress but also to 
inhibit carbohydrate hydrolyzing enzymes and thus preventing hyperglycemia $[5,6]$. Therefore, this class of compounds generally possesses high antioxidant and antidiabetes potencies. However, systematic screening of common plants to correlate the relationships of their polyphenolic contents with their biological activities has yet to be investigated in edible plants from Benin.

The aim of the present work was to study and to evaluate the biological activities of both plants as an $\alpha$ glucosidase inhibitor, an antioxidant, and an antibacterial.

\section{Methods}

\section{Chemicals}

$\alpha$-Glucosidase from Saccharomyces cerevisiae EC.3.2.1.20, 4-Nitrophenyl $\alpha$-D-glucopyranoside, Acarbose, L-Ascorbic acid, 2,4,6-Tris(2-pyridyl)-s-triazine (TPTZ); 2,2'-Azobis (2-methyl-propionamidine) dihydrochloride; Fluorescein Sodium Salt, Folin-Denis' reagent, 2,2-diphenyl-1picrylhydrazyl, Gallic acid, Quercetin, Vanillin, (+)-Catechin hydrate, Iron(II) sulfate heptahydrate, were purchased from Sigma (St Quentin Fallavier, France). Iron (III) chloride hexahydrate and Sodium carbonate were purchased from Prolabo (Fontenay-sous-Bois, France). Phosphate buffered saline was purchased from Gibco, and anhydrous Aluminum chloride was purchased from Acros Organics (Halluin, France).

\section{Microorganisms}

Bacillus subtilis (ATCC 633), Clostridium difficile (ATCC 9689), Enterococcus faecalis (ATCC 29212), Staphylococcus aureus (ATCC 25923), Escherichia coli (ATCC 8739), Pseudomonas aeruginosa (ATCC 27853), Klebsiella pneumoniae LM21 (Favre-Bonte, 1999) and Candida albicans (ATCC 10231) were kindly provided by the LMGE. All these strains were kept frozen at $-80^{\circ} \mathrm{C}$ in appropriate media with $15 \%$ of glycerol.

\section{Collection of plant materials and preparation of extracts}

Different parts of the studied plants were chosen in the light of a bibliographic survey on traditional medicinal plants. Identification of the plants was done in the field by a botanist from the National Herbarium of Bénin (HNB). Polygonum senegalensis leaves harvested in February 2010 in Adjohoun and the roots of Pseudocedrela kotschyi (Schweinf) in September 2009 in GbegourouBinassi in the north of Bénin. These species, which belong to the families Polygonaceae, and Meliaceae respectively, were identified and a voucher was kept at the HNB under the respective numbers: AA6384/HNB and AA6389/HNB.

One hundred $g$ of plant powder was poured into $1000 \mathrm{ml}$ of hydroalcoholic solution $(50 \% \mathrm{v} / \mathrm{v})$, the whole mixture was then mechanically stirred for $3 \mathrm{~h}$, at $25^{\circ} \mathrm{C}$.
The solution was left for $1 \mathrm{~h}$ to settle. It was then filtered with Whatman $\mathrm{N}^{\circ} 1$ paper using a Buchner and a vacuum pump. The filtrates were collected and evaporated in a rotary evaporator at $40^{\circ} \mathrm{C}$. The crude extracts obtained were stored at $-18^{\circ} \mathrm{C}$ until use.

\section{Phytochemical analysis \\ Preliminary qualitative phytochemical screening}

For each extract, colorimetric tests were used to reveal the families the compounds belong to, such as the foam index technique, the Shibata test and Fehling's test which respectively identifies Saponins, flavonoids and reducing compounds [7]. Tannins were revealed using $\mathrm{FeCl}_{3}$ and Stiasny's reagent according to Soro et al. [8] and Dragendorff's test for alkaloids [9].

\section{Determination of total phenolic content}

Total phenolic contents were determined using FolinDenis' reagent following a slightly modified method of Ferreira et al. [10]. A mixture of $10 \mu \mathrm{l}$ of plant extract, $790 \mu \mathrm{l}$ of distilled water and $50 \mu \mathrm{l}$ of Folin reagent was vigorously homogenized. After $5 \mathrm{~min}, 150 \mu \mathrm{l}$ of sodium carbonate $7.5 \%(\mathrm{w} / \mathrm{v})$ were added and the reaction mixture was incubated at room temperature for $30 \mathrm{~min}$. The absorbance was then measured at $760 \mathrm{~nm}$ using the UV-vis spectrophotometer 1800 Shimadzu (Kyoto, Japan). Gallic acid was used as a reference and for the calibration curve; results were expressed in gram of gallic acid equivalent per $\mathrm{g}$ of dry weight (DW).

\section{Total flavonoid content}

The total flavonoid content was determined according to Quettier-Deleu et al. using $\mathrm{AlCl}_{3}$ [11]. This method is based on the formation of a flavonoid-aluminum complex with maximum absorbance at $430 \mathrm{~nm}$ : $500 \mu \mathrm{l}$ of extract was added to the solution of $\mathrm{AlCl}_{3}(2 \%(\mathrm{~m} / \mathrm{v})$ in methanol) following incubation for $15 \mathrm{~min}$ at room temperature, the absorbance of the mixture was measured at $430 \mathrm{~nm}$ with a UV-vis spectrophotometer type Shimadzu UV-vis 1800 . The flavonoid content was calculated from a quercetin standard curve and expressed in mg quercetin equivalent per $\mathrm{g}$ of DW.

\section{Condensed tannins content}

Condensed tannins content was determined according to Price et al. [12]. To $200 \mu \mathrm{l}$ of extract, $1 \mathrm{ml}$ of methanolic solution of vanillin [mixture of equal volumes of $8 \%(\mathrm{v} / \mathrm{v}) \mathrm{HCl}$ at $37 \%$ in methanol and $4 \%$ $(\mathrm{m} / \mathrm{v})$ vanillin in methanol] was added. The mixture was kept at $30^{\circ} \mathrm{C}$ for $20 \mathrm{~min}$ and the absorbance read at $500 \mathrm{~nm}$ using a spectrophotometer Shimadzu UV-vis 1800. The tannins content was calculated from catechin standard curves, and expressed in $\mathrm{mg}$ catechin per $\mathrm{g}$ of DW. 


\section{Biological effects a- Glucosidase inhibitory activity}

The slightly modified method of Rao et al. [13] was adopted to determine the $\alpha$-glucosidase's inhibitory activity. Briefly, in a 96-well microplate $100 \mu \mathrm{l}$ of a sample of different concentrations was incubated with $50 \mu \mathrm{l} \alpha-$ glucosidase $(1.0 \mathrm{U} / \mathrm{ml})$ (from Saccharomyces cerevisiae) in phosphate buffer $(0.1 \mathrm{M}, \mathrm{pH} 6.8)$ for $10 \mathrm{~min}$ at $37^{\circ} \mathrm{C}$. The reaction was initiated by addition of $50 \mu \mathrm{l}$ of substrate: $5 \mathrm{mM}, p$-nitrophenyl- $\alpha-\mathrm{D}$ glucopyranoside in a $0.1 \mathrm{M}$ phosphate buffer at $\mathrm{pH}$ 6.8. P-nitrophenol's release kinetics were measured spectrophotometrically with a microplate spectrophotometric reader Multiskan MS $^{\text {тs }}$ (Labsystems, Minneapolis, USA) for $5 \mathrm{~min}$ with intervals of 30 seconds at $405 \mathrm{~nm}$. Acarbose was used as reference. The $\mathrm{IC}_{50}$ (concentration required to decrease the reaction rate to $50 \%$ ) was then determined from the concentration-dependence curve.

\section{Antioxidant activity}

2, 2-diphenyl-1-picrylhydrazil (DPPH) radical scavenging assay Free radical scavenging activity was determined using 2,2-diphenyl-1-picrylhydrazil (DPPH), as described by Povichit et al. with slight modifications [14]. Briefly, in a 96 well microplate, $180 \mu \mathrm{l}$ of DPPH solution $\left(6.10^{-5} \mathrm{M}\right.$ in Methanol) and $20 \mu \mathrm{l}$ of the plant extract at different concentrations were added. The reaction mixture was shaken and incubated in the dark for $30 \mathrm{~min}$ at $37^{\circ} \mathrm{C}$. The absorbance was read at $540 \mathrm{~nm}$ against blank using the microplate spectrophotometric reader. Ascorbic acid was used as positive control. DPPH radical scavenging activity was calculated according to the formula:

$$
[(\text { Abs. of control - Abs. of sample }) / \text { Abs. of control }] * 100
$$

And the $\mathrm{IC}_{50}$ value for each sample was calculated from the non-linear regression curve.

Ferric reducing/antioxidant power (FRAP) assay The ferric reducing property of the extract was determined by using the assay described by Piljac-Zegarac et al. [15] and Mukherjee et al. [16] with slight modifications. Briefly $180 \mu \mathrm{l}$ of a freshly prepared solution of FRAP reagent (mixture solutions: $300 \mathrm{mM}$ acetate buffer, $\mathrm{pH}$ 3.6, $10 \mathrm{mM}$ TPTZ in $\mathrm{HCl} 40 \mathrm{mM}$ and $\mathrm{FeCl}_{3} \cdot 6 \mathrm{H}_{2} \mathrm{O} 20 \mathrm{mM}$ at a ratio of 10: $1: 1$ at $37^{\circ} \mathrm{C}$ ) are distributed in each well of a plate with $20 \mu \mathrm{l}$ of sample. After briefly vortexing and $4 \mathrm{~min}$ of incubation in the dark, the absorbance of the colored product (ferrous tripyridyl triazine complex) was read at $595 \mathrm{~nm}$ using the microplate spectrophotometric reader. The standard curve was linear between 16 and $250 \mu \mathrm{M} \mathrm{FeSO} 4.7 \mathrm{H}_{2} \mathrm{O}$. Results were expressed in $\mu \mathrm{mol}$ Fe II per $\mathrm{g}$ of DW.

Oxygen Radical Absorbance Capacity (ORAC) assay ORAC assay was carried out as described by $\mathrm{Ou}$ et al. [17]. The reaction was performed at $37^{\circ} \mathrm{C}$ with a microplate fluorescent reader Fluoroskan Ascent $\mathrm{FL}^{\mathrm{rm}}$ (Labsystems, Minneapolis, USA) at an excitation wavelength of $485 \mathrm{~nm}$ and an emission wavelength of $530 \mathrm{~nm}$. In each well, $50 \mu \mathrm{l}$ of fluorescein, (78 nM in PBS $75 \mathrm{mM}, \mathrm{pH} 7$ ) and $50 \mu \mathrm{l}$ of sample, PBS (blank) or trolox (standard) were added. The plate was then incubated at $37^{\circ} \mathrm{C}$ for $10 \mathrm{~min}$. The oxidation reaction was then initiated by adding $25 \mu \mathrm{l}$ of 2, 2-azobis-(2amidinopropane) dihydrochloride (AAPH, $221 \mathrm{mM})$. Finally the absorbance was read at $\mathrm{t}=0$ and every $5 \mathrm{~min}$ until the fluorescence intensity became less than $5 \%$ of its initial reading value.

ORAC values are expressed as $\mu \mathrm{mol}$ Trolox equivalents per gram of dry matter, through the calculation of net AUC. Net AUC is the net area under the fluorescein decay curve.

$$
\begin{aligned}
& \text { AUC }=\left(\mathbf{1}+\mathbf{f}_{\mathbf{5}} / \mathbf{f}_{\mathbf{0}}+\mathbf{f}_{\mathbf{1 0}} / \mathbf{f}_{\mathbf{0}}+\ldots \mathbf{F}_{\mathbf{n}+\mathbf{5}} / \mathbf{f}_{\mathbf{0}}\right) * \mathbf{5} \\
& f_{0}=\text { initial fluorescence } f_{n+5}=\text { fluorescence at time (in min) }
\end{aligned}
$$

Dichlorofluorescin diacetate ( DCFH-DA Cell-based assay ) Antioxidant activities on cells were evaluated using the compound $2^{\prime}, 7^{\prime}$-Dichlorofluorescein diacetate (DCFH-DA) probes [18].

L-929 cells were cultured in Minimum Essential Medium with Glutamax ${ }^{\circledR}$ (Gibco-BRL) complemented with $10 \%(\mathrm{v} / \mathrm{v})$ fetal calf serum (Gibco-BRL), Gentamicine (Gibco-BRL) $4 \mu \mathrm{g} / \mathrm{ml}$, sodium pyruvate $10 \mathrm{mM}$, vitamins and free amino acids mixture (Gibco-BRL). For each experiment, cells were plated in black flat clear bottom 96well microplates at $5 \times 10^{4}$ cells per well and incubated for $24 \mathrm{~h}$ at $37 \mathrm{C}$ and $5 \% \mathrm{CO}_{2}$. After elimination of the medium, the microplates were incubated for $30 \mathrm{~min}$ with $100 \mu \mathrm{l} \mathrm{HBSS} /$ Hepes (15 mM, pH 7.4) containing $20 \mu \mathrm{M}$ DCFH-DA. The cells were then washed with $200 \mu \mathrm{l}$ of HBSS/ Hepes. To assess antioxidant activity, the cells were incubated with increasing concentrations of extracts in the absence or presence of $200 \mu \mathrm{M}$ tertbutylhydroperoxide (t-BuOOH). Fluorescence was measured immediately after $\mathrm{t}-\mathrm{BuOOH}$ addition and every $30 \mathrm{~min}$ during $90 \mathrm{~min}$ on the microplate fluorescent reader using an excitation wavelength of $485 \mathrm{~nm}$ and an emission wavelength of $530 \mathrm{~nm}$. Results are express as $\mathrm{IC}_{50}$ (concentration required to decrease the reaction rate to 50\%) is then determined using the concentration-dependent curve. 


\section{Antibacterial assays}

The cells from the stock cultures were inoculated in Müller-Hinton Broth (MHB) and incubated at $37^{\circ} \mathrm{C}$ under stirring for $24 \mathrm{~h}$. The suspensions were then diluted with fresh MHB to achieve optical density $(620 \mathrm{~nm})$ of $10^{6} \mathrm{col}-$ ony forming units per $\mathrm{ml}(\mathrm{CFU} / \mathrm{ml})$. Dilutions to get the final concentration ranging from 0.156 to $10 \mathrm{mg} / \mathrm{ml}$ of extract in $\mathrm{MHB}$ were prepared in a 96-well microtiter plates in a volume of $100 \mu \mathrm{l}$. Finally $100 \mu \mathrm{l}$ of each microorganism suspension $\left(10^{6} \mathrm{CFU} / \mathrm{ml}\right)$ were added. A negative control composed of $100 \mu \mathrm{l}$ of microorganism suspension and $100 \mu \mathrm{l}$ of MHB was also included. The Minimum Inhibitory Concentration (MIC) was determined as the lowest concentration of the test samples that inhibited the growth of the tested microorganisms by visual assessment.

\section{Statistical analysis}

All experiments were performed at least in triplicate, and results are expressed as mean \pm SEM. Statistical analysis was performed using the statistical software XLSTAT (version 2012. 1.01, Addinsoft, Paris, France). The results are analyzed by the univariate ANOVA test followed by Dunnett/Tukey test for multiple comparisons and determination of significance level. Group means were considered to be significantly different at $\mathrm{P}<0.05$.

\section{Results}

\section{Phytochemical analysis}

As shown in Table 1, the presence of flavonoids, tannins, saponins and reducing compounds seem to be present in the extracts in significant amount. Conversely, the alkaloids were rare. The spectrophotometric results indicated that all the extracts contained significant amounts of total polyphenolic compounds, flavonoids and condensed tannins (Table 2). There was a significant difference in the flavonoids and condensed tannins concentration in both extracts. A higher concentration of flavonoids was found in the extract of P. senegalensis, but the tannin content was almost the same.

\section{a- Glucosidase inhibitory activity}

$\alpha$-Glucosidase inhibitors (AGIs) were among the available glucose-lowering medications. The glucosidase enzyme is located in the brush border of the small intestine

Table 1 Total chemical composition of the studied extracts

\begin{tabular}{lcc}
\hline Chemical composition & $\boldsymbol{P}$. kotschyi & $\boldsymbol{P}$. senegalensis \\
\hline Flavonoids & +++ & +++ \\
Tannins & +++ & +++ \\
Alkaloids & - & + \\
Saponins & +++ & +++ \\
Reducing compounds & +++ & +++ \\
\hline
\end{tabular}

- = Negative result, $+=$ Positive result,$+++=$ Very high concentration.
Table 2 Total phenolics, flavonoids and condensed tannins contents

\begin{tabular}{lccc}
\hline Extracts & $\begin{array}{c}\text { Polyphenolics } \\
\text { content } \\
\text { mg GAE/g DW }\end{array}$ & $\begin{array}{c}\text { flavonoids } \\
\text { content } \\
\text { mg QE/g DW }\end{array}$ & $\begin{array}{c}\text { Condensed } \\
\text { tannins content } \\
\text { mg CE/g DW }\end{array}$ \\
\hline P. kotschyi & $91 \pm 2^{\mathrm{b}}$ & $0.24 \pm 0,01^{\mathrm{b}}$ & $456 \pm 105^{\mathrm{a}}$ \\
P. senegalensis & $126 \pm 8^{\mathrm{a}}$ & $8 \pm 1^{\mathrm{a}}$ & $488 \pm 52^{\mathrm{a}}$ \\
\hline
\end{tabular}

In each column, the means with different symbol superscript $a$ or $b$ showed $a$ significant difference at $\mathrm{P}<0.05$.

and is required for the breakdown of carbohydrates and absorption of monosaccharids. The AGIs delay, but do not prevent, the absorption of ingested carbohydrates, reducing the postprandial glucose and insulin peaks [19]. Testing the $\alpha$-glucosidase inhibitory effect of those four plants, might contribute to the understanding of their mechanisms of action.

The $\alpha$-glucosidase inhibitory activity of the extracts of both plant species were compared on the basis of their $\mathrm{IC}_{50}$ values obtained. $\alpha$ - glucosidase inhibitory activity was observed with $\mathrm{IC}_{50}$ values of $1.50 \pm 0.06 \mu \mathrm{g} / \mathrm{ml}$ in $P$. senegalensis, and $5.0 \pm 0.2 \mu \mathrm{g} / \mathrm{ml}$ in $P$. kotschyi. Figure 1 showed that the extracts displayed strong $\alpha$-glucosidase inhibitory activity in a dose dependent manner, with a significant difference in the inhibitory activity between both extracts $(\mathrm{p}<0.0001)$. Moreover, each extract showed higher $\alpha$-glucosidase inhibitory activity than the reference compound acarbose $\left(\mathrm{IC}_{50} 726 \pm 15 \mu \mathrm{g} / \mathrm{ml}\right)$.

\section{Antioxidant activity}

Several antioxidant assays are frequently used to estimate antioxidant capacities in fresh fruits and vegetables, these assays can roughly be classified into two types: assays based on hydrogen atom transfer (HAT) reactions and assays based on electron transfer (ET) [20]. In this work, we tested two types of ET assay: 2, 2- diphenyl-1 -picrylhydrazyl (DPPH) and Ferric Reducing Antioxidant

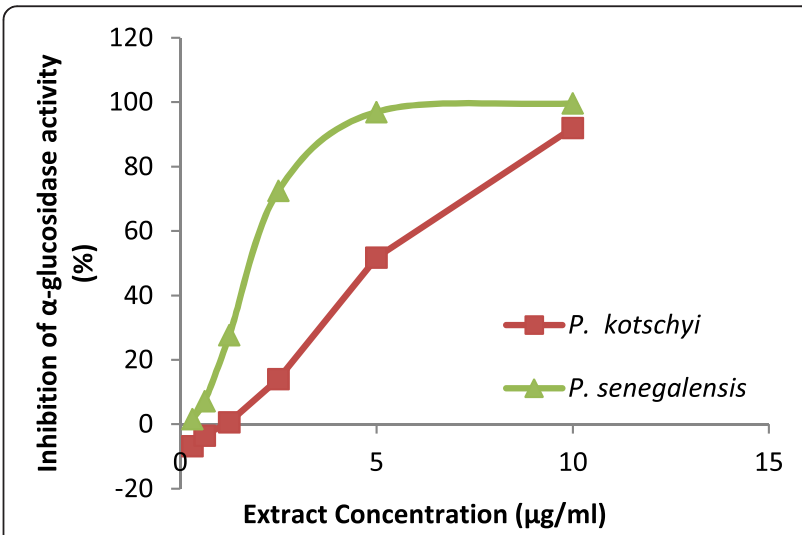

Figure 1 The a-glucosidase inhibitory activity of the extracts of the two plants at increasing concentrations. 
Power (FRAP) and one HAT assay: Oxygen Radical Absorption Capacity (ORAC).

Antioxidant activity results are shown in Figure 2. $\mathrm{DPPH}$ radical scavenging activities of the different extracts are shown in Figure $2 \mathrm{~A}$ by the value of their $\mathrm{IC}_{50}$ : P. kotschyi $(6.7 \pm 0.4 \mu \mathrm{g} / \mathrm{ml}), P$. senegalensis $(6.8 \pm$ $0.4 \mu \mathrm{g} / \mathrm{ml}$ ) and the positive control L-ascorbic acid was $1.25 \pm 0.07 \mu \mathrm{g} / \mathrm{ml}$.

The FRAP assay measures the reducing potential of an antioxidant that reacts with a ferric tripyridyltriazine (Fe3+-TPTZ) complex to produce a colored ferrous tripyridyltriazine (Fe2+-TPTZ). The FRAP values of the two extracts were: $5.0 \pm 0.3 \mu \mathrm{mol}$ Fe II / g DW for $P$. senegalensis and $(2.3 \pm 0.3 \mu \mathrm{mol}$ Fe II / g DW) for $P$. kotschyi. There is a statistically significant difference between the two extract (Figure 2B). ORAC assay is widely employed to determine antioxidant content of foods using fluorescein as a probe for oxidation by peroxyl radical. Figure $2 \mathrm{C}$ shows the ORAC values of the extracts.

Therefore, a one-dimensional assay protocol cannot be used alone to test all relevant parameters. A complementary method used to evaluate the antioxidant activities of fruit and vegetable extracts directly in living mammalian cells could be useful. Unfortunately, very few studies had used cell culture models to evaluate antioxidant potential. The intracellular reactive oxygen accumulation as reflected by the DCFH fluorescence was measured in this assay. DCFH-DA is a useful indicator of reactive oxygen species (ROS) and oxidative stress. The non-polar and non-ionic DCFH-DA cross cell membranes and are hydrolyzed by intracellular esterase to non-fluorescent $2^{\prime}$, $7^{\prime}$-dichlorofluorescin (DCFH). In the presence of ROS such as hydrogen peroxide $\left(\mathrm{H}_{2} \mathrm{O}_{2}\right)$, lipid hydroperoxides or peroxinitrites, DCFH is oxidized to fluorescent $2^{\prime}$, $7^{\prime}$-dichlorofluorescein (DCF). Therefore, DCFH is useful to indirectly measure the effect of intracellular antioxidant activities in scavenging the ROS and in protecting the $\mathrm{DCFH}$ from the oxidation [20]. The value of $\mathrm{IC}_{50}$ was expressed in $\mu$ g equivalent of gallic acid per $\mathrm{ml}$ of extract. The $\mathrm{IC}_{50}$ was calculated and demonstrated that gallic acid $(1.8 \mu \mathrm{g} / \mathrm{ml})$, P. Senegalensis $(2.3 \mu \mathrm{g} \mathrm{GA} / \mathrm{ml})$, P. Kotschyi $(6.3 \mu \mathrm{g} \mathrm{GA} / \mathrm{ml})$ extracts have good activity on ROS inhibition in cells (Figure 2D).

\section{Antibacterial activity}

Table 3 shows the MICs of plant extracts against the 7 tested bacteria and the yeast. None of the plant extract was able to impair growth of all the 8 microorganisms
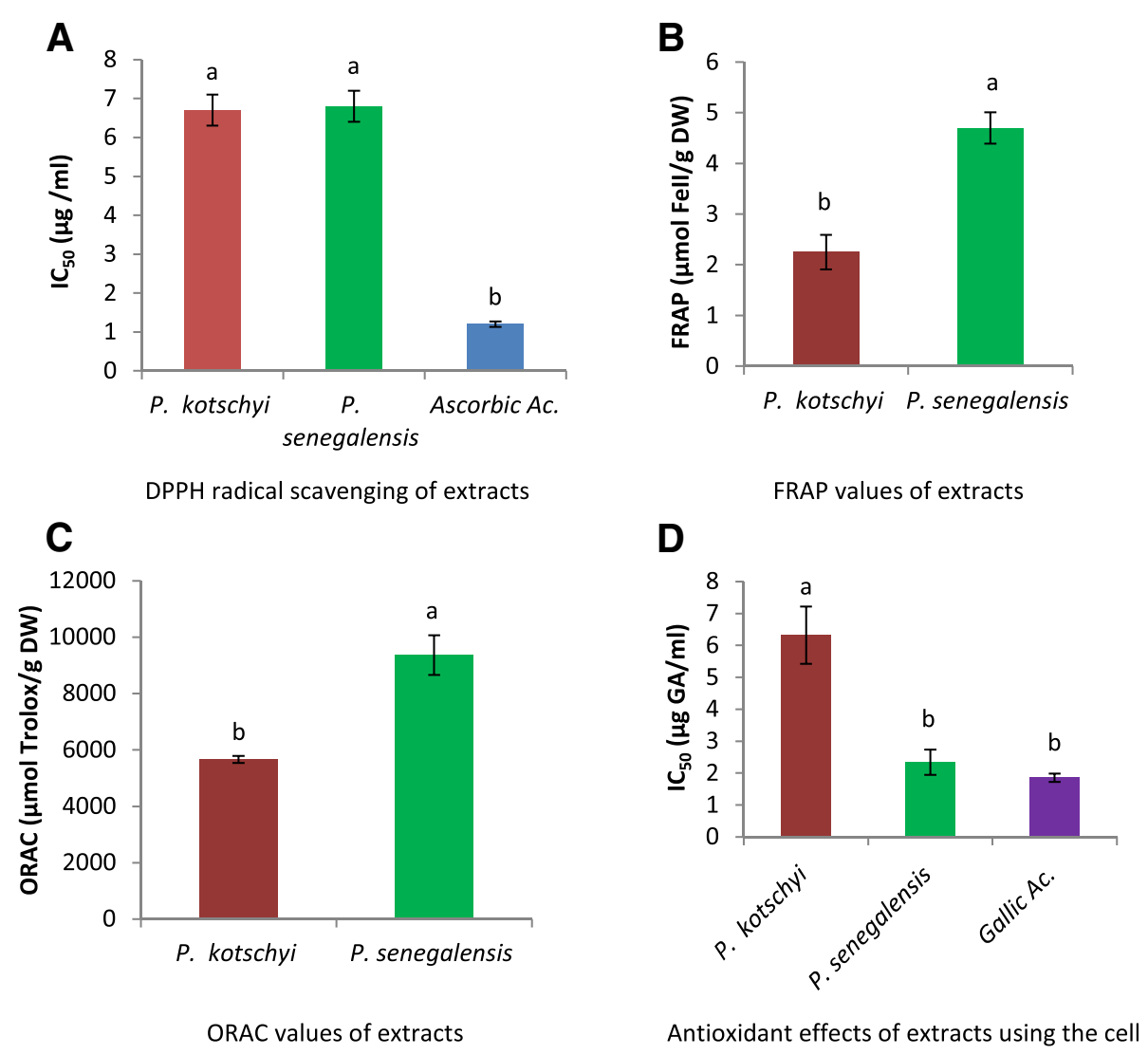

Figure 2 Antioxidant activity of extracts. A: 2, 2-diphenyl-1-picrylhydrazil (DPPH) radical scavenging, B: Ferric Reducing Antioxidant Power (FRAP) values, C: Oxygen Radical Absorbance Capacity (ORAC), D: Antioxidant effects of extracts using the DCFH-DA cell-based assay. 


\begin{tabular}{|c|c|c|c|}
\hline \multirow[t]{2}{*}{ Microorganism } & \multicolumn{3}{|c|}{ Extract } \\
\hline & & P. senegalensis & P. kotschyi \\
\hline & B. subtilis & 5 & 10 \\
\hline \multirow[t]{4}{*}{ Gram-positive } & C. difficile & ND & ND \\
\hline & E. faecalis & 1,25 & 20 \\
\hline & S. aureus & 5 & 5 \\
\hline & E. coli & ND & ND \\
\hline \multirow[t]{2}{*}{ Gram-negative } & K. pneumoniae & ND & ND \\
\hline & P. aeruginosa & ND & ND \\
\hline Yeast & C. albicans & 20 & 20 \\
\hline
\end{tabular}

ND $=$ not detected.

tested and the growth inhibitions observed were strain related (Table 3). Indeed, $C$. albicans growth was inhibited by all plant extracts at concentration of $20 \mathrm{mg} /$ ml. Among the tested bacteria, B. subtilis, E. faecalis and $S$. aureus growth were inhibited at concentration equal to $20 \mathrm{mg} / \mathrm{ml}$ or even lower with $P$. senegalensis extract for E. faecalis.

\section{Discussion}

The aim of the present study was to establish the potential $\alpha$-glucosidase, antioxidant and antimicrobial activities of hydro-alcoholic extract of two plants used in traditional medicine in Benin: Polygonum senegalensis, and Pseudocedrela kotschyi.

Type 2 diabetes is an endocrine disease, which accounts for $9 \%$ of deaths worldwide. The aim of oral therapy is to reach normoglycemia to prevent later complications. Among glucose-lowering medications, $\alpha$-glucosidase inhibitors which delay the absorption of ingested carbohydrates, reduces the postprandial glucose and insulin peaks [21]. Acarbose represents a pharmacological approach to achieving the metabolic benefits of a slower carbohydrate absorption in diabetes, by acting as a potent competitive inhibitor of intestinal $\alpha$-glucosidases. Acarbose molecules attach to the carbohydrate binding sites of $\alpha$-glucosidases, with a much higher affinity constant than the normal substrate [21]. However, the conversion of oligosaccharides to monosaccharides is only delayed rather than completely blocked due to the reversible nature of the inhibitor-enzyme interactions.

In our study acarbose was used as the positive control; it inhibited the $\alpha$-glucosidase activity with an $\mathrm{IC}_{50}$ value estimated at $765 \mu \mathrm{g} / \mathrm{ml}$ while the $\mathrm{IC}_{50}$ values of the extracts ranged from 1.5 to $5 \mu \mathrm{g} / \mathrm{ml}$. This indicates that the extracts are very potent $\alpha$-glucosidase inhibitors in comparison with acarbose. Only a few articles had discussed acarbose effect in detail [22-25]. In those studies acarbose was found to exert little inhibition on $\alpha$-glucosidase activity $\left(\mathrm{IC}_{50} \geq\right.$
$1000 \mu \mathrm{g} / \mathrm{ml}$ in each case) and authors justified this by the nature of $\alpha$-glucosidase enzyme which were from mammalian (rat intestine), bacterial (Bacillus stearothermophilus), and yeast (Saccharomyces cerevisiae) sources. This could justify why all extracts studied here were more active against this enzyme than acarbose. Furthermore, the nature of some extract constituents (phenolics, flavonoids and their glycosides) is in accordance with previous reported works as being effective inhibitors of $\alpha$-glucosidases [26-29]. For example, water extract of P. kotschyi leaves was evaluated by Udeme et al. on blood glucose in alloxan-induced diabetic albino wistar rats [3]. To the best of our knowledge, nothing has been reported on $P$. senegalensis's AGI properties. Here, our results show that both plant species contained active principle(s) which could back up their use in the treatment of type 2 diabetes. It would be interesting to know which molecule or group of molecules are responsible of this activity in each extract. Biological effect-guided fractionation is currently in progress.

The present work also involved the evaluation of the antioxidant activity of these extracts. The two in vitro electron transfer methods (DPPH and FRAP) presented consistent results: when the extract showed low $\mathrm{IC}_{50}$ value using DPPH test, it exhibited a high FRAP value. Moreover, our investigation on the ability of both extracts to transfer a hydrogen atom showed a high potency with a high ORAC value in both cases. This activity may be due to the presence of phenolic compounds in the extract [30]. Generally, the reducing properties are associated with the presence of compounds which exert their action by breaking the free radical chain through the donation of a hydrogen atom [31]. The ability of these compounds to give hydrogen atoms may be due to their polyphenolic nature. Excepted the antiradical activity of essential oils from P. kotschyi root barks, no work on antioxidant activity of alcohol- or water-soluble extract of both plants was previously described [32].

Antioxidants are particularly interesting in drug discovery [33]. Several techniques are used for the determination of antioxidants in plant extracts, however these techniques have some limitations [34,35]. However, in vitro tests do not take into account the cells' physiological conditions, the antioxidant molecules' bioavailability and the general cellular metabolism. Therefore, in this study, a complementary method was used to evaluate the antioxidant activities of the two extracts directly in living mammalian cells. In the presence of ROS such as hydrogen peroxide (H2O2), lipid hydroperoxides and peroxinitrites, DCFH were oxidized to fluorescent $2^{\prime}, 7^{\prime}$-dichloro-fluorescein (DCF) [18]. The two extracts showed the capacity to reduce $\mathrm{tBuOOH}$-induced DCFH oxidation in cells, especially $P$. senegalensis extracts. 
Altogether, our results show that antioxidant activities measured with the cell-based assay are in good agreement with the values obtained using FRAP and ORAC assay. It would be interesting to isolate some polyphenols present in the studied samples to see whether the antioxidant activity on cell-based assay is due to a synergistic effect or not.

Polyphenolic compounds in plants have long been recognized to inhibit the activities of digestive enzymes because of their ability to bind with proteins. Various in vitro assays have shown that many plant polyphenols possess carbohydrate hydrolyzing enzyme inhibitory activities $[26,28,29]$. Since these molecules exert antioxidant effect, it is likely that antioxidant and $\alpha$-glucosidase inhibitory properties should come from polyphenolic contents.

Phytochemical constituents such as tannins, flavonoids, alkaloids and several other aromatic compounds are secondary metabolites of plants which are used as defense mechanisms against predation by many microorganisms, insects and herbivores [36]. Regarding the absence of data on antibacterial properties, the Minimum Inhibitory Concentration (MIC) method was used to determine the antibacterial activity. Our results suggest moderate effect on Gram-positive bacteria while Gram-negative bacteria were found to be less sensitive to the extracts. A possible explanation for these observations may lie in the significant differences in the outer layers of Gram-negative and Gram-positive bacteria. Gram-negative bacteria possess an outer membrane and a unique periplasmic space not found in Gram-positive bacteria [37]. The resistance of Gram-negative bacteria towards antibacterial substances is related to the hydrophilic surface of their outer membrane which is rich in lipopolysaccharide molecules. These properties constitute a barrier to the penetration of numerous antibiotic molecules. It is also associated with the enzymes in the periplasmic space, which are capable of breaking down the molecules introduced from outside [38]. Grampositive bacteria do not have such an outer membrane and cell wall structure. Antibacterial substances can easily destroy the bacterial cell wall and cytoplasmic membrane which results in leakage and coagulation of the cytoplasm [39]. The resistance of the Gram-positive C. difficile to extracts could be due to its strict anaerobic metabolism, there is no study to justify this yet.

\section{Conclusion}

The results obtained in this study support the use of $P$. senegalensis (leaves) and of $P$. kotschyi (root) as traditional medicinal plants in Benin against some disorders such as hyperglycemia. Our study indicated that these plants possess $\alpha$-glucosidase inhibitory activity, and potent antioxidant effect. These effects were slightly more pronounced in $P$. senegalensis than in $P$. kotshyi and further investigations of the active natural compound(s) of these plants are in progress. This work is an important step in exploring the pharmacological effect of plants traditionally used in Benin.

\section{Abbreviations}

DW: Dry weight; DPPH: 2, 2-diphenyl-1-picrylhydrazil; FRAP: Ferric reducing/ antioxidant power; ORAC: Oxygen Radical Absorbance Capacity; DCFH -

DA: Dichlorofluorescin diacetate; MHB: Müller-Hinton Broth; MIC: Minimum Inhibitory Concentration; AGl: a-Glucosidase inhibitors; HAT: Hydrogen atom transfer; ET: Electron transfer; $\mathrm{Fe}^{+} / 2^{+}$-TPTZ: Ferric/Ferrous tripyridyltriazine.

\section{Competing interests}

The authors declare that they have no competing interests.

\section{Authors' contributions}

FTDB conducted experiments on glucosidase, antioxidant and antibacterial activities, statistical analysis and the draft of the manuscript. ED was responsible for conception and design of the study, statistical analysis and revised the manuscript critically for important intellectual content. CF supervised antibacterial activities. FA participated in design of the study and preparation of the manuscript. DS and JT were revised it critically for important intellectual content. All authors read and approved the final manuscript.

\section{Acknowledgements}

FB acknowledges the Embassy of France in Benin, the Ministry of Higher Education and Scientific Research of Benin for the generous fellowship to carry out this work in France and UMR INSERM 990 of Clermont-Ferrand, France for the laboratory facilities offered. The authors thank William Tottey for his revision of the manuscript.

\section{Author details}

'Clermont University, Université d'Auvergne, IMTV, Clermont-Ferrand F-63000, France. ${ }^{2}$ INSERM, UMR 990, IMTV, Clermont-Ferrand F-63005, France.

${ }^{3}$ University of Abomey Calavi, Laboratoire d'étude et de Recherche en chimie Appliquée, Ecole Polytechnique d'Abomey Calavi, Cotonou, Benin. ${ }^{4}$ Clermont University, Université d'Auvergne, Laboratoire Microorganismes: Génome et Environnement (LMGE), Clermont-Ferrand BP 10448, F-63000, France. ${ }^{5}$ CNRS, UMR 6023, LMGE, Aubiere F-63177, France.

Received: 3 September 2012 Accepted: 25 February 2013

Published: 1 March 2013

\section{References}

1. Lee J, Koo N, Min DB: Reactive oxygen species, aging, and antioxidative nutraceuticals. Compr Rev Food Sci F 2004, 3:22-33.

2. World Health Organization: Who launches the first global strategy on traditional medicine. Geneva:. Press release WHO 2002/38. http://www.who. int/mediacentre/news/releases/release38/en/.

3. Udeme OG, Owunari AG: Effect of extract of Pseudocedrela kotschyi on blood glucose concentration of alloxan induced diabetic albino rats. East J Med 2009, 14:17-19.

4. Asase A, Kokubun T, Grayer RJ, Kite G, Simmonds MS, Oteng-Yeboah AA, Odamtten GT: Chemical constituents and antimicrobial activity of medicinal plants from Ghana: Cassia sieberiana, Haematostaphis barteri, Mitragyna inermis and Pseudocedrela kotschyi. Phytother Res 2008, 22:1013-1016.

5. de Sousa E, Leila Zanatta IS, Creczynski-Pasa TB, Pizzolatti MG, Szpoganicz B, Barreto Silva FRM: Hypoglycemic Effect and Antioxidant Potential of Kaempferol-3,7-O-(r)-dirhamnoside from Bauhinia forficata Leave. J Nat Prod 2004, 6:829-832.

6. Hanamura T, Toshihiko H, Hirokazu K: Structural and functional characterization of polyphenols isolated from acerola (Malpighia emarginata DC.) fruit. Biosci Biotechnol Biochem 2005, 69:280-286.

7. Karumi Y, Onyeyili PA, Ogugbuaja VO: Identification of active Principles of M. balsamina (Balsam Apple) Leaf Extract. Int J Med Sci 2004, 4:179-182.

8. Soro TY, Traore F, Datte JY, Nene-Bi AS: Activité antipyrétique de l'extrait aqueux de Ximenia americana. Phytothérapie 2009, 7:297-303. 
9. Mowla A, Alauddin M, Atiar Rahman M, Kabir A: Antihyperglycemic effect of trigonella foenum-graecum (fenugreek) seed extract in alloxan-induced diabetic rats and its use in diabetes mellitus: a brief qualitative phytochemical and acute toxicity test on the extract. Afri J Tradit Complement Altern Med 2009, 6:255-261.

10. Ferreira E, Rita AN, Souza B, Batista AR: Effect of drying method and length of storage on tannin and total phenol concentrations in Pigeon pea seeds. Food Chem 2004, 86(1):17-23.

11. Quettier-Deleu C, Gressier B, Vasseur J, Dine T, Brunet C, Luyckx M, Cazin M, Cazin JC, Bailleul F, Trotin F: Phenolic compounds and antioxidant activities of buckwheat hulls and flour. J Ethnopharmacol 2000, 72:35-42.

12. Price ML, Van Scoyoc S, Butler LG: A critical evaluation of the vanillin reaction as an assay for tannin in sorghum grain. J Agric Food Chem 1978, 26:1214-1218.

13. Rao RR, Tiwari AK, Reddy PP, Babu KS, Ali AZ, Madhusudana K, Rao JM: New furanoflavonoids, intestinal a-glucosidase inhibitory and free radical [DPPH) scavenging, activity from antihyperglycemic root extract of Derris indica (Lam). Bioorg Med Chem 2009, 17:5170-5175.

14. Povichit N, Ampai P, Maitree S, Chaiyavat C, PimpornLee I: Phenolic content and in vitro inhibitory effects on oxidation and protein glycation of some Thai medicinal plants. Pak J Pharm Sci 2010, 23:403-408.

15. Piljac-Žegarac J, Stipčević T, Belščak A: Antioxidant properties and phenolic content of different floral origin honeys. J Apiprod Apimed Sci 2009, 1:43-50.

16. Mukherjee S, Nayana P, Omkar K, Bhagyashri N, Shrikant T, Akshay B, Pankaj $P$ : Evaluation of free-radical quenching properties of standard ayurvedic formulation Vayasthapana rasayana. BMC Complem Altern M 2011, 11:38.

17. Ou B, Hampsch-Woodill M, Ronald L: Prior: development and validation of an improved oxygen radical absorbance capacity assay using fluorescein as the fluorescent probe. J Agric Food Chem 2001, 49:4619-4626.

18. Girard-Lalancette K, Pichette A, Legault J: Sensitive cell-based assay using DCFH oxidation for the determination of pro- and antioxidant properties of compounds and mixtures: Analysis of fruit and vegetable juices. Food Chem 2009, 115:720-726

19. Stuart AR, Gulve EA, Minghan W: Chemistry and biochemistry of type 2 diabetes. Chem Rev 2004, 104:1255-1282.

20. Huang D, Ou B, Prior RL: The chemistry behind antioxidant capacity assays. J Agric Food Chem 2005, 53:1841-1856.

21. Salvatore T, Giugliano D: Pharmacokinetic-pharmacodynamic relationship of acarbose. Clin Pharmacokinet 1996, 30:94-106.

22. Youn JY, Park HY, Cho KH: Anti-hyperglycemic activity of Commelina communis L. inhibition of a-glucosidase. Diabetes Res Clin Pract 2004, 66S: S149-S155.

23. Shinde J, Taldone T, Barletta M, Kunaparaju N, Hu B, Kumar S, Placido J, Zito SW: a-Glucosidase inhibitory activity of Syzygium cumini (Linn.) Skeels seed kernel in vitro and in Goto-Kakizaki (GK) rats. Carbohydr Res 2008 343:1278-1281.

24. Liu Y, Chen L, Yuan P, Cui W, Kang W: a-glucosidase inhibitory and antioxidant activities of Polygonum longisetum De Bruyn in vitro. Modern Pharm Res 2009, 2:16-21.

25. Hsieh PC, Guan-Jhong H, Yu-Ling H, Yaw-Huei L, Shyh-Shyun H, Ying-Chen C, Mu-Chuan T, Yuan-Shiun C: Activities of antioxidants, a-Glucosidase inhibitors and aldose reductase inhibitors of the aqueous extracts of four Flemingia species in Taiwan. Bot Stud 2010, 51:293-302.

26. Jung M, Park M, Chul HL, Kang Y, Seok-Kang E, Ki-Kim S: Antidiabetic agents from medicinal plants. Curr Med Chem 2006, 13:1-16.

27. Apostolidis EM, Young-In Ms Kalidas S: Potential of cranberry-based herbal synergies for diabetes and hypertension management. Asia Pac J Clin Nutr 2006, 15:433-441.

28. Mai TT, Nghiem NT, Pham GT, Nguyen VC: Alpha-glucosidase inhibitory and antioxidant activities of Vietnamese edible plants and their relationships with polyphenol contents. J Nutr Sci Vitaminol 2007, 53:267-276.

29. Myung-Hee K, Sung-Hoon J, Hae-Dong J, Mee Sook L, Young-In K: Antioxidant activity and a-glucosidase inhibitory potential of onion (Allium cepa L.) extracts. Food Sci Biotechnol 2010, 19:159-164.

30. Sadhu SK, Okuyama E, Fujumoto H, Ishibashi M: Separation of leucas, asparaa medicinal plant of Bangladesh, guided by prostaglandin inhibitory and anti-oxidant activities. Chem Pharm Bull 2003, 51:595-598.

31. Benzie Iris FF, Szeto YT: Total antioxidant capacity of teas by the ferric reducing/ antioxidant power assay. J Agric Food Chem 1999, 47:633-636.

32. Fekam BF, Amvam Zollo PH, Agnaniet H, Menut C, Bessière JM: Aromatic plants of tropical central Africa. Part XLIII† volatile components from pseudocedrela kotschyi (schweinf.) harms growing in Cameroon. Flavour Fragr J 2004, 19:9-11.

33. Naylor MA, Thomson P: Recent advances in bioreductive drug targeting Mini Rev Med Chem 2001, 1:17-29.

34. Prior RL, Wu X, Schaich K: Standardized methods for the determination of antioxidant capacity and phenolics in foods and dietary supplements. J Agric Food Chem 2005, 53:4290-4302.

35. Aruoma OI: Methodological considerations for characterizing potential antioxidant actions of bioactive components in plant foods. Mutat Res 2003, 523-524:9-20.

36. Marjorie MC: Plant products as antimicrobial agents. Clin Microbiol Rev 1999, 12:564-582.

37. Duffy CF, Power RF: Antioxidant and antimicrobial properties of some Chinese plant extracts. Int J Antimicrob Agents 2001, 17:527-529.

38. Gao Y, van Belkum MJ, Stiles ME: The outer membrane of Gram-negative bacteria inhibits antibacterial activity of brochocin-C. Appl Environ Microbiol 1999, 65:4329-4333.

39. Kalemba D, Kunicka A: Antibacterial and antifungal properties of essential oils. Curr Med Chem 2003, 10:813-829.

doi:10.1186/1472-6882-13-51

Cite this article as: Bothon et al:: In vitro biological effects of two antidiabetic medicinal plants used in Benin as folk medicine. BMC Complementary and Alternative Medicine 2013 13:51.

\section{Submit your next manuscript to BioMed Central and take full advantage of:}

- Convenient online submission

- Thorough peer review

- No space constraints or color figure charges

- Immediate publication on acceptance

- Inclusion in PubMed, CAS, Scopus and Google Scholar

- Research which is freely available for redistribution
C Biomed Central 